\title{
Rooting responses of black pepper (Piper nigrum cv. Bragantina) as affected by chemical, physical and microbiological properties of substrates and auxin
}

\section{Robson Rangel Freire ${ }^{1}$, Edilson Romais Schmildt ${ }^{2}$, José Carlos Lopes ${ }^{3}$, Kristhiano Chagas ${ }^{4}$, Helder Ivo Pandolfi Marques $^{2}$, Joel Cardoso Filho ${ }^{2}$, João Paulo Bestete de Oliveira ${ }^{5}$, Wagner Campos Otoni ${ }^{4}$, Rodrigo Sobreira Alexandre ${ }^{* 6}$}

\author{
${ }^{1}$ Municipal Secretary of the Environment Victoria. Vitória-ES, Brazil \\ ${ }^{2}$ Federal University of Espírito Santo, Department of Agricultural and Biological Sciences, Brazil \\ ${ }^{3}$ Federal University of Espírito Santo, Department of Plant Production, Brazil \\ ${ }^{4}$ Federal University of Viçosa, Department of Plant Biology, Viçosa, MG, Brazil \\ ${ }^{5}$ Federal Institute of Espírito Santo, Campus Ibatiba, Brazil \\ ${ }^{6}$ Federal University of Espírito Santo, Department of Forest and Wood Sciences, Brazil
}

*Corresponding author: rodrigosobreiraalexandre@gmail.com

\begin{abstract}
The quality of the root system in stem cuttings of Piper nigrum is highly associated with the induction of adventitious roots by means of auxins and type of substrates. The objective of this study was to evaluate the rooting of P. nigrum cv. Bragantina cuttings treated or not with indole-3-butyric acid (IBA) in different substrates. The experiment was conducted in a randomized block design following a factorial $2 \times 11$ scheme (IBA -0 and $4000 \mathrm{mg} \mathrm{kg}^{-1}$ in talc and 11 substrates), with four repetitions of 16 cuttings each. The auxin increased rooting and improved the quality of the root system. The substrates evaluated presented diverse physical, chemical and microbiological characteristics, interfering significantly in the rooting responses. Substrates $(d)-$ soil + limestone + single superphosphate + potassium chloride + chicken manure and (i) - soil + coffee straw + limestone + single superphosphate are the ones recommended for rooting of pepper cv. Bragantina.
\end{abstract}

Key words: Piper nigrum L., vegetative propagation, indole-3-butyric acid, substrates, rooting.

Abbreviation: IBA_ indole-3-butyric acid, IBGE_ Instituto Brasileira de Geografia e Estatística, KIN_ kinetin, GA $3_{-}$gibberellic acid, NAA_naphthaleneacetic acid, OM_organic matter, HS_ humic substances, FA_fulvic acids, HA_ humic acids, $\mathrm{H}^{+}$-ATPase_ proton pump (enzyme), MAPA_ Ministério da Agricultura Pecuária e Abastecimento, TP_ total porosity, AS_ aeration space, WA_ water availability, WR_ water remainder.

\section{Introduction}

The black pepper ( $P$. nigrum L.) is a perennial woody vine species largely traded worlwide as condiment, medicinal purposes, and other uses such as as phytolarvicides in control of dengue insect (Aedes aegypti) (Simas et al., 2007; Grzybowski et al., 2012). Despite the high number of catalogued varieties (around 51) by Mathew et al. (2001) in India, in Brazil, the production relies on the Bragantina variety, mainly in pepper nurseries of northern Espírito Santo state. The black peppercorm production in this state was about 7.640 tonnes in 2015 (TV Gazeta, 2015 ), representing around $14.46 \%$ of the total brazilian production, with the highest national income (IBGE, 2015). The current price of black pepper kilogram is approximately US\$7.6.

The implementation costs of black pepper orchards are relatively high, which implies on the use of superior varieties and high phytosanitary quality of propagative material. However, the low quality of root systems and rates of rooting responses, and the low quality of planting material, remain as the main dissatisfaction reasons for black pepper growers. Vegetative propagation by means of rooting cuttings is the main means to generate planting material for black pepper
(Abassi et al., 2010). In this sense, auxin has proven hability to stimulate Therefore, auxins like IBA has proven stimulation on rhizogenesis in the species (Secundino et al., 2014).

Another important issue involved in generating highquality propagative material is the quality of the substrate, especially regarding their chemical, physical and microbiological characteristics. It is essential to be free of pathogens and seeds of weeds. This way, the substrate should sustain plant growth by providing nutrients, and have sufficient porosity to enable adequate aeration to the root system and good drainage, while maintaining adequate moisture for plant growth (Zietemann \& Roberto (2007). There are several commercial substrates for the production of plantlets of different species, however, burden production leading nurseries to produce their own substrate. However, there are few studies aiming at evaluating optimal substrate composition or to validate existing ones in the production of black pepper plantlets. The objective was to verify the rooting responses of the black pepper $\mathrm{cv}$. Bragantina cuttings as affected by the presence or absence of IBA, in different substrates used by nurseries. 


\section{Results and Discussion}

\section{Rizogenesis: effect of auxin}

Black pepper cuttings from cultivar Bragantina exposed or not to IBA (4000 mg kg ${ }^{-1}$ in talc) showed 76.63 and $27.75 \%$ rooting, respectively (Table $3 \mathrm{~A})$. Total immersion of the cuttings in IBA (4000 mg kg-1 in talc) was recommended for the Iaçará and Guajarina cultivars, whereas for cultivar Bragantina it was recommended only the immersion of the basal region of the cuttings (Secundino et al., 2014). Serrano et al. (2012) used IBA (2000 mg kg-1) in the clonal production of the cultivars Guajarina, Iaçará and Cingapura. Some commercial growth regulator formulations such as Serradix $^{\circledR}$ (Cardoso, 1961; Anandaraj and Sarma, 1994), Vigortone $^{\circledR}$ (Cardoso, 1961) and and Stimulate ${ }^{\circledR}$ [kinetin KIN $\left(0.09 \mathrm{~g} \mathrm{~L}^{-1}\right)+$ gibberellic acid - $\mathrm{GA}_{3}\left(0.05 \mathrm{~g} \mathrm{~L}^{-1}\right)+\mathrm{IBA}$ $\left.\left(0.05 \mathrm{~g} \mathrm{~L}^{-1}\right)\right]$ or auxins like naphthaleneacetic acid - NAA (50 $\mathrm{mg} \mathrm{L^{-1 }}$ ), beta-indoleacetic acid $\left(50 \mathrm{mg} \mathrm{L}^{-1}\right.$ ) (Leite \& Inforzato, 1966), IBA (50 $\left.\mathrm{mg} \mathrm{L}^{-1}\right)$ (Thanuja et al., 2002), IBA (2000 mg kg${ }^{-1}$ in talc) (Serrano et al., 2012), IBA (Secundino et al., 2014) were used to promote rooting of cuttings $P$. nigrum.

The auxins increased the sugar content of the cuttings which improved rooting hability (Agulló-Antón et al., 2011). According to Husen \& Pal (2007) the IBA activates the metabolism of sugars and releases energy, protein and increases the activity of peroxidases necessary for cell division and differentiation at the initiation of root primordia. The rooting of olive cuttings treated with IBA (2000 $\left.\mathrm{mg} \mathrm{L}^{-1}\right)$ was $76 \%$ and coincided with the greatest concentration of soluble sugars, especially glucose and less starch (Denaxa et al., 2012).

The IBA induced average 1.61 nodal roots and its absence in 0.57 by nodal cutting roots (Table $3 \mathrm{~A}$ ). This may be related the injury on the basis of $P$. nigrum cuttings which stimulated phenolic oxidation and causing necrosis and death of some tissue in this region lessening rooting responses. Nodal cuttings of Bambusa vulgaris had greater rooting percentages when exposed to IBA ( $8000 \mathrm{mg} \mathrm{L}^{-1}$ ) (Islam et al., 2011). In the absence of nodal roots, only the basal root system was able to maintain the continued growth of the bud (Thomas \& Hay, 2010). The development of axillary buds was positively regulated by a signal from the roots (ex.: cytokinin synthesis as zeatin and zeatin riboside) of ryegrass (Wang et al., 2014). Therefore, the root node produced in the stem near the axillary bud establishes a more effective connection system for transporting water, nutrients, organic compounds and plant growth regulators such as cytokinins.

\section{Rizogenesis: substrates effect}

Among the substrates studied rooting percentages ranged from $46.09 \%$ for substrate (j) and $67.96 \%$ for (k) (Table 3B), which resulted in loss of cuttings from 53.91 to $32.04 \%$, respectively. Other substrates, such as (j) and (c) led to low rhizogenesis (Table 3B). The explanation may rely in the least amount of organic matter - OM (0.9 e $1.4 \mathrm{dag} \mathrm{kg}^{-1}$, respectively) (Table 1). Prezotti et al. (2007) considered the values of $<1.5$; 1.5-3.0 and $>3.0 \mathrm{dag} \mathrm{dm}^{-3} \mathrm{OM}$ as low, medium and high levels of $\mathrm{OM}$, respectively. The $\mathrm{OM}$ consists of humic substances (HS) as fulvic acids (FA) and humic acids (HA), where the latter has auxin-like activity (O'Donell, 1973). Auxinic groups in the structure of HA indicates a relationship between the induction and activation of plasma membrane $\mathrm{H}^{+}$-ATPase with hormonal activity of AH (Façanha et al., 2002). However, there was no statistical difference between the substrates studied on the number of nodal roots and therefore all belong to a single group (Table 3B).

\section{Rizogenesis: effect of IBA $x$ substrate interaction}

For the number of basal and total roots, nodal length, total volume and total dry mass of roots, there was a significant interaction between the use of different substrates and IBA. In this case, it turns on all substrates in the formation, growth in size, volume and mass of the total roots and the use of auxin was greater than its absence (Table 4). Among the substrates that have a higher number of basal and total roots, (d) presented pH 6.3 (Table 1). According to Abreu et al. (2012), the $\mathrm{pH}$ range generally recommended for most cultures is from 5.0 to 6.5 . This is related to the adequate availability of nutrients and the subsequent physiological vigor of the plantlets.

The substrates (e) and (i) with higher levels of OM 2.7 and $2.4 \mathrm{dag} \mathrm{kg}^{-1}$, respectively (Table 1) were those with the highest basal respiration rates (Figure 1). According to Silva et al. (2012), the basal respiration is a soil quality indicator for the presence of microorganisms, expressing the metabolic activity of the living fraction of the microbial biomass. This increase in metabolic activity can be attributed to dehydrogenases stimulated by organic substrate material (Garcia et al., 1997).

In guava, the highest of rooting rates were associated with the $\mathrm{P}$ content (average $110 \mathrm{mg} \mathrm{dm}^{-3}$ ) of the substrates (Batista et al., 2011), which may partly explain the low rooting in the substrate (e), probably due to the low content of this element (41.4 $\left.\mathrm{mg} \mathrm{dm}^{-3} \mathrm{P}\right)$. The substrate (i) has high values of root dry matter (Table 4), and this can be correlated to the presence of humic acids (HA) and the high content of $\mathrm{P}$ $\left(292.2 \mathrm{mg} \mathrm{dm}^{-3}\right)$ (Table 1).

Corn seedlings showed an increase in the number of mitosis and lateral roots in treatment HA (Aguiar et al., 2009). According to these authors, the activity of plasm membrane $\mathrm{H}^{+}$-ATPase increases by the action of HA. Cuttings Codianeum variegatum $\mathrm{L}$. Rumph e Hibiscus rosa-sinensis $\mathrm{L}$. as treated with 579 and $970 \mathrm{mg} \mathrm{L}^{-1}$ IBA and 14 and $50 \mathrm{mmol}$ $\mathrm{L}^{-1} \mathrm{C}$ HA it was those that promote greater dry matter accumulation in the root system, respectively (Baldotto et al., 2012).

The length of the roots of $\mathrm{cv}$. Bragantina was stimulated by the presence of IBA ( $4000 \mathrm{mg} \mathrm{kg}^{-1}$ ), regardless the substrate (Table 4). The substrate (i) and (f) had a higher mean of particle diameter (Table 2B), whereas substrate (i) also had the largest total porosity, lower density, larger air space (Table 2A) and basal respiration (Figure 1).

The total volume of roots in planted cuttings, all substrates, was statistically favored by IBA, highlighting substrates (d) and (i) (Table 4). However, the root volume was lower in cuttings planted in substrate (j), which was also less effective in promoting basal root (Table 4). This substrate has features like low $\mathrm{pH}$, low $\mathrm{OM}$ (Table 1), lower basal respiration (Figure 1) and less water available (Table 2A). The low quality of the root system in the substrate (j) could also be linked to a deficiency of soil amendments, for example, limestone in its composition. The substrate (j) had the lowest amount of base saturation (77.1\%) (Table 1). In the production of seedlings of Psidium guajava L., limestone benefited the root system, increasing the length in a dosedependent manner according to the dose escalation (Prado \& Natale, 2004).

The dry weight of roots for cv. Bragantina with IBA (4000 $\mathrm{mg} \mathrm{kg}^{-1}$ ) ranged from $0.168 \mathrm{~g}$ for substrate (j) to $0.505 \mathrm{~g}$ for 
Table 1. Chemical analysis of the substrates used in the black pepper cultivar Bragantina nurseries.

\begin{tabular}{|c|c|c|c|c|c|c|c|c|c|c|c|c|}
\hline \multirow{2}{*}{$\begin{array}{l}\text { Chemical } \\
\text { analysis }\end{array}$} & & \multicolumn{11}{|c|}{ Substrates } \\
\hline & & $\mathrm{a}$ & $\mathrm{b}$ & $\mathrm{c}$ & $\mathrm{d}$ & $\mathrm{e}$ & $f$ & $\mathrm{~g}$ & $\mathrm{~h}$ & $\mathrm{i}$ & $\mathrm{j}$ & $\mathrm{k}$ \\
\hline $\mathrm{pH}\left(\mathrm{H}_{2} \mathrm{O}\right)^{1}$ & & 7.7 & 7.1 & 7.0 & 6.3 & 7.4 & 6.9 & 6.5 & 7.1 & 7.2 & 5.4 & 6.9 \\
\hline $\mathrm{P}_{2} \mathrm{O}_{5}{ }^{2}$ & & 74.1 & 285.8 & 301.6 & 226.5 & 41.4 & 190.9 & 287.8 & 279.8 & 292.2 & 285.6 & 64.0 \\
\hline $\mathrm{K}_{2} \mathrm{O}^{2}$ & & 539 & 924 & 891 & 352 & 1529 & 385 & 1463 & 946 & 671 & 616 & 572 \\
\hline $\mathrm{Na}^{2}$ & & 22 & 99 & 198 & 55 & 11 & 11 & 121 & 110 & 88 & 110 & 44 \\
\hline $\mathrm{Fe}^{2}$ & & 38 & 24.6 & 44.2 & 47.4 & 52.6 & 77.7 & 55.3 & 31.8 & 37.7 & 89.5 & 51.2 \\
\hline $\mathrm{Cu}^{2}$ & ? & 0.1 & 1.9 & 0.8 & 1.0 & 0.8 & 0.1 & 0.4 & 8.7 & 0.7 & 0.1 & 0.1 \\
\hline $\mathrm{Zn}^{2}$ & E & 5.0 & 7.8 & 17.3 & 5.9 & 2.0 & 1.0 & 3.0 & 39.2 & 10.7 & 3.4 & 1.9 \\
\hline $\mathrm{Mn}^{2}$ & $\stackrel{\infty}{\Xi}$ & 10.9 & 10.5 & 26.3 & 28.6 & 5.5 & 8.3 & 8.0 & 37.8 & 103.0 & 21.4 & 22.5 \\
\hline $\mathrm{Ca}^{3}$ & & 3.5 & 2.7 & 7.3 & 4.6 & 2.9 & 5.8 & 2.3 & 3.5 & 5.8 & 5.5 & 2.6 \\
\hline $\mathrm{Mg}^{3}$ & & 1.4 & 1.1 & 1.7 & 1.1 & 1.5 & 0.8 & 2.1 & 2.4 & 1.1 & 1.3 & 0.8 \\
\hline $\mathrm{Al}^{\circ}$ & & 0.1 & 0.1 & 0.1 & 0.1 & 0.1 & 0.1 & 0.2 & 0.1 & 0.1 & 0.3 & 0.1 \\
\hline $\mathrm{H}+\mathrm{Al}^{4}$ & 3 & 0.2 & 0.7 & 1.0 & 1.0 & 0.8 & 0.7 & 1.5 & 0.2 & 0.2 & 2.6 & 0.2 \\
\hline SB & $\xi$ & 6.4 & 6.7 & 12.1 & 6.8 & 8.4 & 7.6 & 8.6 & 8.8 & 9.0 & 8.9 & 5.1 \\
\hline CTC (t) & 0 & 6.5 & 6.7 & 12.2 & 6.9 & 8.4 & 7.7 & 8.8 & 8.8 & 9.1 & 9.1 & 5.1 \\
\hline CTC (T) & & 6.6 & 7.3 & 13.1 & 7.8 & 9.2 & 8.3 & 10.1 & 9.0 & 9.2 & 11.5 & 5.2 \\
\hline $\mathrm{OM}^{5}$ & 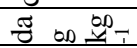 & 2.0 & 1.4 & 1.4 & 1.6 & 2.7 & 1.2 & 1.4 & 0.9 & 2.4 & 0.9 & 1.2 \\
\hline Sat. Ca & & 53.5 & 37.5 & 55.4 & 58.3 & 31.7 & 69.9 & 22.9 & 39.0 & 63.1 & 48.0 & 50.2 \\
\hline Sat. Mg & & 21.6 & 15.3 & 13.1 & 14.5 & 16.3 & 9.7 & 20.3 & 26.8 & 12.3 & 11.4 & 15.0 \\
\hline Sat. K & & 20.9 & 32.3 & 17.4 & 11.5 & 42.5 & 11.9 & 36.9 & 27.0 & 18.7 & 13.7 & 27.9 \\
\hline M & & 0.8 & 0.7 & 0.4 & 0.7 & 0.6 & 0.7 & 1.7 & 0.6 & 0.6 & 2.7 & 1.0 \\
\hline $\mathrm{V}$ & $\delta^{\circ}$ & 97.5 & 91.0 & 92.5 & 87.4 & 91.0 & 92.0 & 85.3 & 98.2 & 98.2 & 77.1 & 96.9 \\
\hline
\end{tabular}

Legend: ${ }^{1} \mathrm{pH}$ in $\mathrm{H}_{2} \mathrm{O} 1: 2,5 ;{ }^{2}$ Extractor: Mehlich $1 ;{ }^{3}$ Extractor: $\mathrm{KCl} 1 \mathrm{~mol} \mathrm{~L}{ }^{-1} ;{ }^{4}$ Titration; ${ }^{5}$ Colorimetric. Substrates: (a) soil C horizon + limestone + single superphosphate + cattle manure; (b) soil C horizon + limestone + single superphosphate + chicken manure; (c) soil C horizon + limestone + single superphosphate + potassium chloride + cattle manure; (d) soil C horizon + limestone + single superphosphate + potassium chloride + chicken manure; (e) soil C horizon + coffee trashing residues; (f) soil C horizon + coffee trashing residues + limestone + single superphosphate; $(\mathrm{g})$ soil C horizon + coffee trashing residues + single superphosphate + cattle manure; $(\mathrm{h})$ soil $\mathrm{C}$ horizon + coffee trashing residues + limestone + single superphosphate + cattle manure; (i) soil C horizon + coffee straw + limestone + single superphosphate; (j) soil C horizon + coffee straw + single superphosphate + cattle manure; $(\mathrm{k})$ soil C horizon + coffee straw + limestone + single superphosphate + cattle manure).

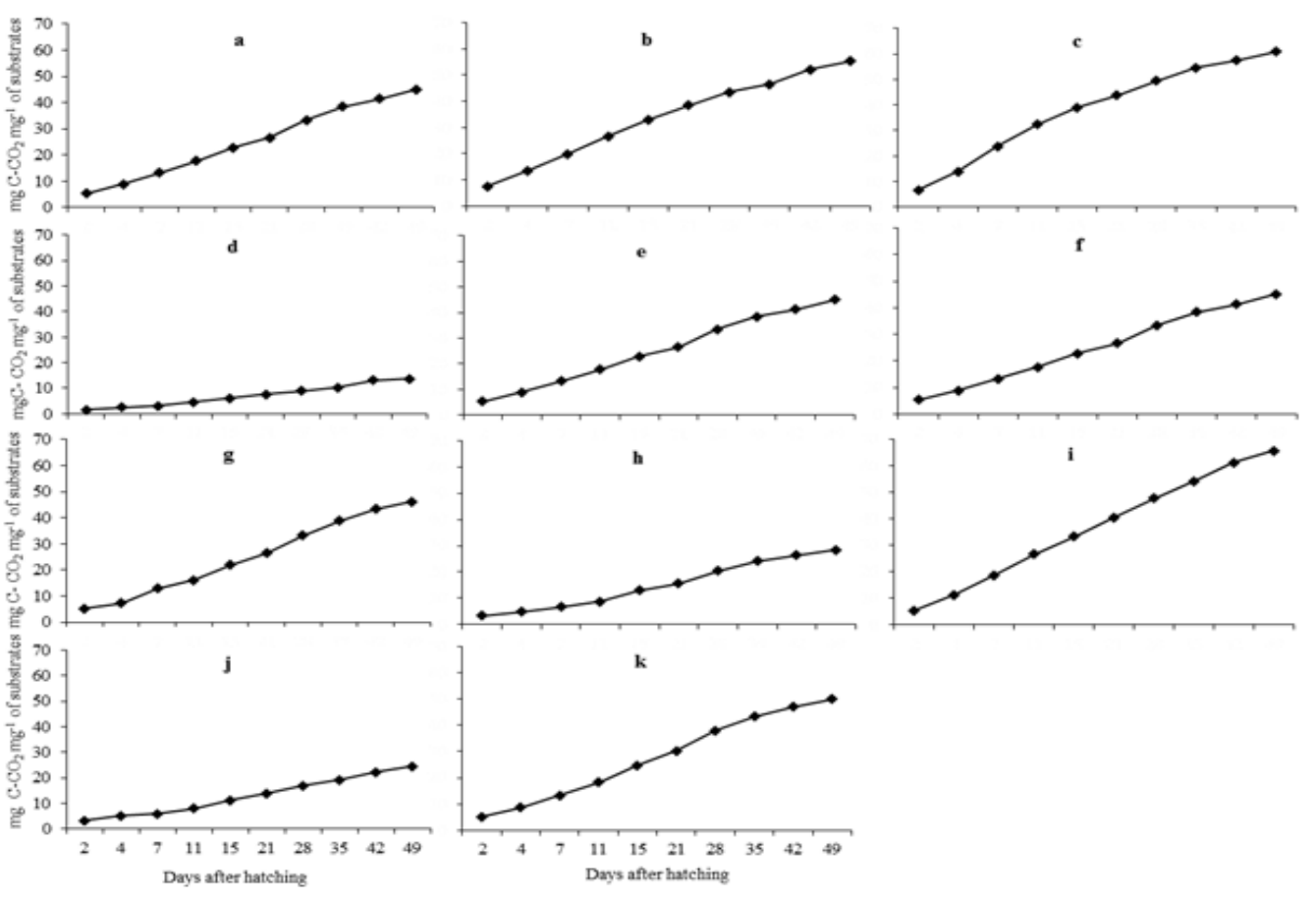

Fig 2. Basal respiration (mg C-CO $\mathrm{CO}_{2} \mathrm{mg}^{-1}$ substrate) the substrates (a-k) used in the black pepper nurseries located in the North Espírito Santo. Substrates: (a) soil C horizon + limestone + single superphosphate + cattle manure; (b) soil C horizon + limestone + single superphosphate + chicken manure; $(\mathrm{c})$ soil $\mathrm{C}$ horizon + limestone + single superphosphate + potassium chloride + cattle manure; (d) soil C horizon + limestone + single superphosphate + potassium chloride + chicken manure; (e) soil C horizon + coffee trashing residues; (f) soil $\mathrm{C}$ horizon + coffee trashing residues + limestone + single superphosphate; $(\mathrm{g})$ soil $\mathrm{C}$ horizon + coffee trashing residues + single superphosphate + cattle manure; (h) soil $\mathrm{C}$ horizon + coffee trashing residues + limestone + single superphosphate + cattle manure; (i) soil C horizon + coffee straw + limestone + single superphosphate; (j) soil C horizon + coffee straw + single superphosphate + cattle manure; $(\mathrm{k})$ soil $\mathrm{C}$ horizon + coffee straw + limestone + single superphosphate + cattle manure). 
Table 2. Physical analysis (PA) and diameter distribution of particles (DDP) of the substrates used in nurseries of the black pepper cultivar Bragantina.

\begin{tabular}{|c|c|c|c|c|c|c|c|c|}
\hline \multicolumn{9}{|l|}{ PA } \\
\hline Substrates & TP & AS & ESW & BW & WA & $\begin{array}{ll}\begin{array}{l}\text { WR } \\
\mathrm{cm}\end{array} & 100 \\
\end{array}$ & $\begin{array}{l}\text { Wet } \\
\text { density }\end{array}$ & $\begin{array}{l}\text { Dry } \\
\text { density }\end{array}$ \\
\hline & & & \multicolumn{4}{|c|}{ 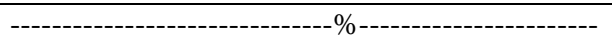 } & \multicolumn{2}{|c|}{ 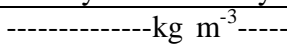 } \\
\hline A & 49 & 10 & 12 & 05 & 17 & 21 & 1000 & 900 \\
\hline B & 48 & 09 & 11 & 03 & 14 & 25 & 1000 & 900 \\
\hline $\mathrm{C}$ & 47 & 06 & 11 & 04 & 14 & 27 & 1100 & 1100 \\
\hline D & 48 & 07 & 12 & 06 & 18 & 23 & 1300 & 1200 \\
\hline $\mathrm{E}$ & 49 & 14 & 07 & 02 & 10 & 24 & 900 & 800 \\
\hline $\mathrm{F}$ & 47 & 09 & 10 & 04 & 14 & 24 & 900 & 800 \\
\hline G & 47 & 10 & 10 & 03 & 13 & 24 & 900 & 900 \\
\hline $\mathrm{H}$ & 49 & 03 & 08 & 05 & 13 & 32 & 1300 & 1100 \\
\hline I & 54 & 12 & 09 & 05 & 14 & 18 & 900 & 800 \\
\hline $\mathrm{J}$ & 52 & 19 & 09 & 02 & 12 & 20 & 1100 & 1000 \\
\hline $\mathrm{K}$ & 43 & 07 & 14 & 05 & 18 & 28 & 1100 & 1100 \\
\hline \multicolumn{9}{|l|}{ DDP (mm) } \\
\hline \multirow[t]{2}{*}{ Substrates } & $<0.25$ & $\begin{array}{l}0.25- \\
0.50\end{array}$ & $\begin{array}{l}0.50- \\
1.00\end{array}$ & $\begin{array}{l}1.00- \\
2.00\end{array}$ & $2.00-4.75$ & $>4.75$ & APD & \\
\hline & \multicolumn{8}{|c|}{ - } \\
\hline $\mathrm{a}$ & 9.4 & 15.8 & 23.8 & 24.2 & 15.2 & 11.3 & 1.73 & \\
\hline $\mathrm{b}$ & 9.8 & 17.9 & 24.9 & 24.6 & 17.1 & 5.4 & 1.49 & \\
\hline $\mathrm{c}$ & 19.6 & 20.1 & 20.1 & 15.0 & 14.5 & 10.5 & 1.49 & \\
\hline d & 18.8 & 25.8 & 24.1 & 14.2 & 11.8 & 5.1 & 1.18 & \\
\hline $\mathrm{e}$ & 5.2 & 14.2 & 27.7 & 22.8 & 15.7 & 14.2 & 1.82 & \\
\hline f & 5.6 & 10.8 & 18.3 & 22.6 & 24.1 & 18.3 & 2.22 & \\
\hline $\mathrm{g}$ & 8.5 & 13.7 & 19.4 & 22.0 & 22.1 & 14.0 & 1.97 & \\
\hline $\mathrm{h}$ & 32.8 & 24.2 & 20.6 & 12.0 & 8.1 & 2.0 & 0.88 & \\
\hline $\mathrm{i}$ & 8.6 & 10.5 & 16.1 & 24.0 & 23.3 & 17.1 & 2.15 & \\
\hline $\mathrm{j}$ & 4.6 & 10.8 & 24.8 & 27.4 & 22.7 & 9.48 & 1.87 & \\
\hline $\mathrm{k}$ & 17.8 & 26.3 & 25.9 & 15.2 & 10.1 & 4.4 & 1.12 & \\
\hline
\end{tabular}

Legend: TP: Total porosity; AS: Aeration space; EAW: Easily available water; BW: Buffering water; WA: Water available; WR: Water remainder; APD: Average particle diameter. Substrates: (a) soil C horizon + limestone + single superphosphate + cattle manure; (b) soil C horizon + limestone + single superphosphate + chicken manure; (c) soil C horizon + limestone + single superphosphate + potassium chloride + cattle manure; (d) soil C horizon + limestone + single superphosphate + potassium chloride + chicken manure; (e) soil C horizon + coffee trashing residues; (f) soil $\mathrm{C}$ horizon + coffee trashing residues + limestone + single superphosphate; (g) soil $\mathrm{C}$ horizon + coffee trashing residues + single superphosphate + cattle manure; (h) soil C horizon + coffee trashing residues + limestone + single superphosphate + cattle manure; (i) soil C horizon + coffee straw + limestone + single superphosphate; $(\mathrm{j})$ soil $\mathrm{C}$ horizon + coffee straw + single superphosphate + cattle manure; $(\mathrm{k})$ soil $\mathrm{C}$ horizon + coffee straw + limestone + single superphosphate + cattle manure).

Table 3. (A) Rooting (\%) basal or nodal cuttings and mean number of adventitious in nodal cuttings treated or not with IBA and (B) Rooting (\%) basal or nodal cuttings and number of nodal roots on different substrates, the black pepper cv. Bragantina.

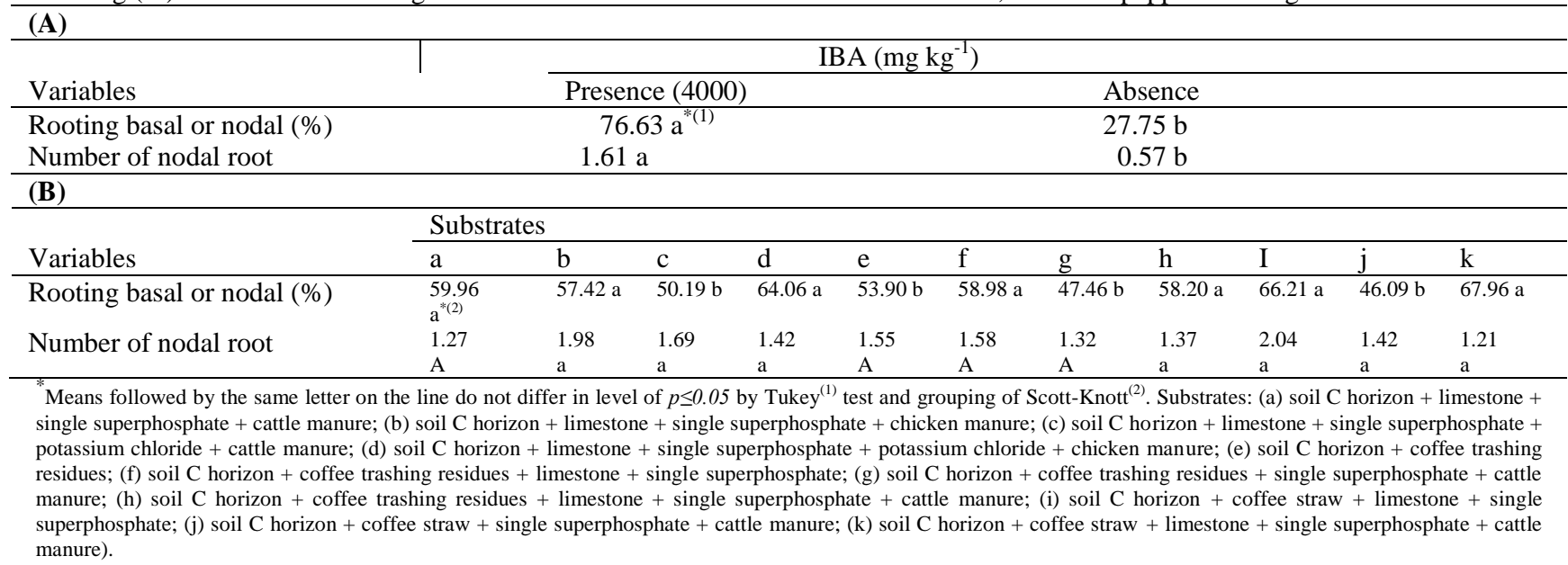


Table 4. Shottings cuttings (\%), number basal of the root, number total of the root, basal length of the root (cm), nodal length of the root $(\mathrm{cm})$, total volume of roots $\left(\mathrm{cm}^{3}\right)$, total dry massa of root $(\mathrm{mg})$ of black pepper cv. Bragantina, in the presence and absence of IBA, substrates used for nursery.

Variables

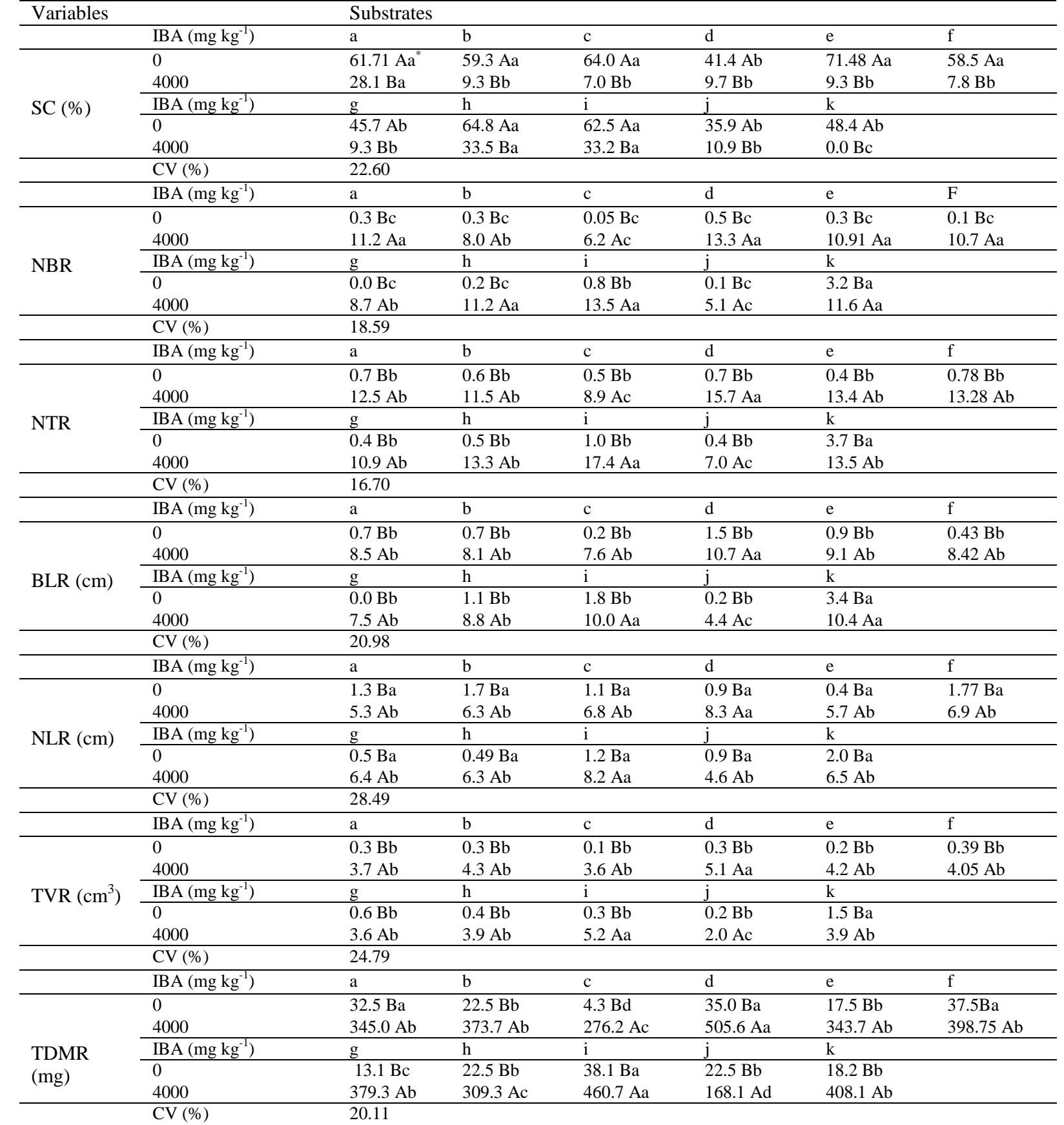

* Means followed by the same letter, lowercase and uppercase on the line in the column, do not differ in level $p \leq 0.05$ for the assembly test Scott-Knott e Tukey, respectively. Legend: EB. Shottings cutting; NBR. Number basal of the root; NTR. Number total of the root; BLR. Basal length of the root; NLR. Nodal length of the root; TVR. Total volume of roots $\left(\mathrm{cm}^{3}\right)$; TDMR. Total dry massa of root $(\mathrm{mg})$. Substrates: (a) soil C horizon + limestone + single superphosphate + cattle manure; (b) soil C horizon + limestone + single superphosphate + chicken manure; (c) soil C horizon + limestone + single superphosphate + potassium chloride + cattle manure; $(\mathrm{d})$ soil $\mathrm{C}$ horizon + limestone + single superphosphate + potassium chloride + chicken manure; (e) soil C horizon + coffee trashing residues; (f) soil C horizon + coffee trashing residues + limestone + single superphosphate; $(\mathrm{g})$ soil $\mathrm{C}$ horizon + coffee trashing residues + single superphosphate + cattle manure; $(\mathrm{h})$ soil $\mathrm{C}$ horizon + coffee trashing residues + limestone + single superphosphate + cattle manure; (i) soil C horizon + coffee straw + limestone + single superphosphate; (j) soil C horizon + coffee straw + single superphosphate + cattle manure; $(\mathrm{k})$ soil $\mathrm{C}$ horizon + coffee st

substrate (d), averaging $0.360 \mathrm{~g}$ by cutting (Table 4). In descending order the dry mass of roots in cuttings of the black pepper cultivars treated with IBA $\left(2.0 \mathrm{~g} \mathrm{~kg}^{-1}\right.$ in talc) it was cvs. Guajariana $(2.12 \mathrm{~g})>$ Iaçara $(1.42 \mathrm{~g})>$ Cingapura ( $0.56 \mathrm{~g})$ (Serrano et al., 2012). This shows the inferiority of cv. Bragantina in relation to cvs. Guajarina and Iaçará the quality of the root system. Use of plant waste or organic compounds on the substrate porosity increases, allowing rapid flow of water, preventing low oxygenation to the roots (Arruda et al., 2007). Possibly the poor drainage in the substrates (c) $(27 \%$ de AR $100 \mathrm{~cm})$ and (h) $(32 \%$ de AR 100 $\mathrm{cm}$ ) coupled with reduced space aeration 6 e $3 \%$ (Table $2 \mathrm{~A}$ ), respectively, have contributed to the poor quality of the root system in these substrates (Table 4). The substrate (j), regardless the presence of IBA, enabled less than $10 \%$ budding (Table 4), confirming the poor performance of this 
substrate in the production of plantlets of cv. Bragantina, to also consider that did not promote good rooting. Conversely, the substrate (k) led to lack of budding in cuttings, however in relation to rooting was always present in the group with the best responses, even without the use of IBA (Table 4). The substrate (k), most likely was the biochemical degradation of caffeine by microorganisms present in the soil coffee straw, which degrade the alkaloid (Sundar-Raj \& Dhala, 1965), for example, by the action of the bacterium Pseudomonas putida (Burr \& César, 1984), as basal respiration this substrate was a major (Figure 1). The existing alkaloid caffeine in coffee husk, whose molecule has the ability to store nitrogen (Mazzafera et al., 1996), which will be available for inclusion in the $\mathrm{C} / \mathrm{N}$ ratio. The substrates (d), (i) and (k) led to better quality of roots linked to the basal respiration with low, high and high metabolic activities, respectively (Figure 1). Although the microbial activity was different when compared with the substrate (d) and (k) and (i), possibly in the types (d), (i) and (k) the number and types of microorganisms can be positively influence the quality of the root system. Although the microbial activity has been different if compared to the substrate (d) with (i) and (k), possibly in (d) time and (i) and (k), the number and type of microorganisms can positively influence the quality of the root system. Brunetta et al. (2007) verified from the 99 tested strains of $P$. taeda, six (UFV AL9, UFV-AM5, UFV-AM2, UFV-F3, UFV-G2 and UFV-G4) stood out due to their capacity of stimulating the growth and quality improvement seedlings. Significant differences were not observed between the control and the other tested strains. Mafia et al. (2009) verified the interaction among isolates of rhizobacteria and Eucalyptus species for seed germinating and seedling growth. MF2 (Pseudomonas sp.) was the best rhizobacteria isolate for growth promotion of E. cloeziana e E. grandis. S1 (Bacillus subtilis) was the most effective for E. globulus, and $\mathrm{Ca}$ (Pseudomonas fulva), MF2 (Pseudomonas sp.), CIIb (Stenotrophomonas maltophilia) and S2 (B. subtilis) were the most promising isolates for the E. urophylla. Microorganisms in the soil are influenced by the changes in $\mathrm{pH}$, moisture, aeration, temperature and nutrient availability in the isolated effect or the sum of these factors (Rodrigues et al., 2011).

The substrates (c) and (j) often appeared in the groups with the worst performance in the quality of the root system showed very different rates in basal respiration rates. The substrate (c) presented respiration rate almost triple the one by substrate (j) (Figure 1).

\section{Materials and Methods}

\section{Location of nurseries in the north of the Espirito Santo}

The experiment was conducted under greenhouse conditions in the municipality of São Mateus, located in Espírito Santo state. Eleven different substrate compositions derived from eleven nurseries in the municipalities of Rio Bananal (2), Jaguaré (2), Vila Valério (1) and São Mateus (6), all located in northern Espírito Santo.

\section{Chemical and physical analysis of the substrates}

Chemical analysis of the substrates was performed as recommend by Silva (2009) and physical analysis in accordance to MAPA (2007) (Table 2A and B). Physical analysis they determined the water content retained in stress $0 ; 10$ e $100 \mathrm{hPa}$. Then the samples were dried at glasshouse $105^{\circ} \mathrm{C}$, of $24 \mathrm{~h}$, and weighed to obtain the water content in each sample, and the dry density of the substrates. It was also determined the total porosity (TP), aeration space (AS), expressed as the the difference between total porosity and the volume of water held in tension $10 \mathrm{hPa}$; water availability (WA), expressed as the volume of water between the voltages $10 \mathrm{hPa}$ and $100 \mathrm{hPa}$; water remainder (WR) expressed as the volume of water in the material after being subjected to tension $100 \mathrm{hPa}$ (MAPA, 2007) (Table 2A). The diameter of the dried particles was determined by sieving the samples, for 10 minutes, through $0.50 ; 1.00 ; 2.00 ; 4.00$ e $7.93 \mathrm{~mm}$ opening mesh sieves, featuring the fractions smaller and more influence on the properties of the substrates (Table 2B).

\section{Microbiological analysis}

Microbiological testing was indirectly assessed by means of basal respiration using the methodology described by Mendonça \& Matos (2005) (mg C-CO $\mathrm{Cg}^{-1}$ in substrate).

\section{Plant materials}

The cuttings used in the experiment were collected from adult (3.5-year-old) donor plants of black pepper cultivar Bragantina, in São Mateus-ES. The cuttings were treated with fungicide Carbendazim ${ }^{\circledR}$, at the concentration of $1 \mathrm{~mL} \mathrm{~L}^{-1}$ of the commercial product, and then half amount of the cuttings were exposed to received IBA the powder formulation of IBA at $4000 \mathrm{mg} \mathrm{kg}^{-1}$ in talc (Secundino et al., 2014); the other half remained without application of auxin. The cuttings were further planted in trays of cells with the respective substrates.

\section{Measured characteristics}

They evaluated the number of cuttings which have lost the leaf after 105 days after planting; survival percentage (\%); percentage of cuttings sprouted (\%); rooting (in any position, either basal or nodal), rooting basal and nodal (\%); number of total basal and nodal roots; length of the largest basal and root nodal $(\mathrm{cm})$; total volume of roots $\left(\mathrm{cm}^{3}\right)$, and root dry weight (mg).

\section{Statistical analysis}

The experiment was conducted in a randomized block design in a factorial $2 \times 11$ (IBA: absence and presence $(4000 \mathrm{mg}$ $\mathrm{kg}^{-1}$ in talc) $\mathrm{x}$ substrates: 11), with four replications of 16 cuttings each, constituting of 64 cuttings per treatment.

Rooting data were subjected to analysis of variance and treatment means in relation to absence and presence of IBA and different substrates were compared by the test Tukey and average grouping Scott-Knott, respectively at $p \leq 0.05$. The percentage data were transformed to arc-sine $\sqrt{\mathrm{x}} / 100$. Analyses were performed using the program Genes (Cruz, 2013).

\section{Conclusions}

Rooting responses and quality of the root system were significantly improved by the use of IBA. The substrates showed distinct physical, chemical and microbiological chraracteristics, interfering significantly in the rooting responses. The substrates (d) and (i) are recommended for rooting of pepper $\mathrm{cv}$. Bragantina. 


\section{Acknowledgements}

We thank the producers of clonal seedlings of black pepper in the northern region of the state of Espirito Santo.

\section{References}

Abbasi BH, Ahmad N, Fazal H \& Mahmood T (2010) Conventional and modern propagation techniques in Piper nigrum. J Med Plants Res. 4: 7-12.

Abreu MF, Dias RS, Abreu CA \& Gonzalez AP (2010) Reavaliação dos critérios constantes na legislação brasileira para análise de substratos. Bragantina. 71: 106-111.

Aguiar NO, Canellas LP, Dobbss LB, Zandonadi DB, Olivares FL \& Façanha AR (2009) Distribuição de massa molecular de ácidos húmicos e promoção do crescimento radicular. R Bras Ci Solo. 33: 1613-1623.

Agulló-Antón MA, Sánchez-Bravo J, Acosta M \& Druege U (2011) Auxins or sugars: what makes the difference in the adventitious rooting of stored carnation cuttings? J Plant Growth Regul. 30: 100-113.

Anandaraj M \& Sarma YR (1994) Effect of vesicular arbuscular mycorrhiza on rooting of black pepper (Piper nigrum L.). J Spices Arom Crops 3: 39-42.

Arruda MR, Pereira JCR, Moreira A \& Teixeira WG (2007) Enraizamento de estacas herbáceas de guaranazeiro em diferentes substratos. Ci Agrotec. 31: 236-241.

Baldotto LEB, Baldotto MA, Soares RR, Martinez HEP \& Alvarez VH (2012) Adventitious rooting in cuttings of croton and hibiscus in response to indolbutyric acid and humic acid. R Ceres. 59: 476-483.

Batista MAV, Prado RM \& Leite GA (2011) Resposta de mudas de genoiabeira a aplicação de fósforo. Bioscience Journal. 27: 423-447.

Brunetta JMFC, Alfenas, AC, Mafia RG, Gomes JM, Binoti DB \& Fonseca NAN (2007) Isolamento e seleção de rizobactérias promotoras do crescimento de Pinus taeda. R Árvore 34: 399-406.

Burr TJ \& Caesar A (1985) Beneficial plant bacteria. Cr R Plant Sci. 2: 1-20.

Cardoso M (1961) Sobre o enraizamento de estacas de pimenteira-do-reino. Bragantia. 20: 529-531.

Cruz CD (2013) Genes: a software package for analysis in experimental statistics and quantitative genetics. Acta Sci-Agron. 35: 271-276.

Denaxa N-K, Vemmos SN \& Roussos PA (2012) The role of endogenous carbohydrates and seasonal variation in rooting ability of cuttings of an easy and a hard to root olive cultivars (Olea europaea L.). Sci Hortic. 143: 1928. http://dx.

Façanha AR, Façanha ALO, Olivares FL, Guridi F, Santos GA, Velloso ACX, Rumjanek V M, Brasil F, Schripsema J, Braz-Filho R, Oliveira MA \& Canellas LP (2002) Bioatividade de ácidos húmicos: efeitos sobre o desenvolvimento radicular e sobre a bomba de prótons da membrana plasmática. Pesq Agropec Bras. 37: 13011310.

Garcia TC, Hernandez T \& Costa F (1997) Potential use of dehydrogenase activity as index of microbial activity in degraded soils. Commun Soil Sci Plant Anal. 28: 12334.
Grzybowski AG, Tiboni M, Silva MAN, Chitolina RF, Passos M \& Fontana JD (2012) The combined action of phytolarvicides for the control of dengue fever vector, Aedes aegypti. R Bras Farm. 22: 549-557.

Husen A \& Pal M (2007) Metabolic changes during adventitious root primordium development in Tectona grandis Linn. f. (teak) cuttings as affected by age of donor plants and auxin (IBA and NAA) treatment. New For. 33: 309-323.

IBGE. 2015. Levantamento Sistemático da produção Agrícola: pesquisa mensal de previsão e acompanhamento das safras agrícolas no ano civil / Fundação Instituto Brasileiro de Geografia e Estatística. Rio de Janeiro: IBGE. 83p.

Islam MS, Bhuiyan MK, Hossain MM \& Hossain MA (2011) Clonal propagation of Bambusa vulgaris by leafy branch cuttings. J For Res. 22: 387-392.

Leite JR \& Inforzato R (1966) Enraizamento de estacas de pimenta-do-reino (Piper nigrum L.). Bragantia. 25: 7-9.

Mafia RG, Alfenas AC, Ferreira EM, Binoti DHB, Mafia GMVM \& Mounteer AH (2009) Root colonization and interaction among growth promoting rhizobacteria isolates and eucalypts species. R Árvore. 33: 1-9.

Mathew PJ, Mathew PM \& Kumar V (2001) Graph clustering of Piper nigrum L. (black pepper). Euphytica. 118: 257-264.

Mazzafera P, Yamaoka-Yano DM, Vitória AP (1996) Para que serve a cafeína em plantas? R Bras Fis Veg. 8: 67-74, 1996.

Mendonça ES \& Matos ES (2005) Matéria orgânica do solo: métodos de análises. Viçosa, Editora UFV, 107p.

MINISTÉRIO DA AGRICULTURA, PECUÁRIA E ABASTECIMENTO - MAPA. Instrução Normativa SDA N 17. (2007). Diário Oficial da União - Seção 1, $n^{\circ}$ 99, 24 de maio de 2007. Métodos analíticos oficiais para análise de substratos para plantas e condicionadores de solo. Brasília.

O'Donnell RW (1973) The auxin-like effects of humic preparations from leonardite. Soil Sci. 116: 106-112.

Prado RM \& Natale W (2004) Calagem na nutrição de cálcio e no desenvolvimento do sistema radicular da goiabeira. Pesq Agropec Bras. 39: 1007-1012.

Prezotti LC, Gomes JA, Dadalto GG \& Oliveira JA (2007) Manual de recomendação de calagem e adubação para o Estado do Espírito Santo - $5^{\mathrm{a}}$ aproximação. Vitória, SEEA/Incaper/Cedagro, 305p.

Rodrigues HJB, Sá LDA, Ruivo MLP, Costa ACL, Silva RB, Moura QL \& Mello IF (2011) Variabilidade quantitativa de população microbiana associada às condições microclimáticas observadas em solo de floresta tropical úmida. R Bras Met. 26: 629-638.

Secundino W, Alexandre RS, Schmildt ER, Schmildt O, Magevski GC \& Martins JPR (2014) Rhizogenic behavior of black pepper cultivars to indole-3-butyric acid. Acta Sci Agron. 36: 355-364.

Serrano LAL, Marinato FA, Magiero M \& Sturm GM (2012) Produção de mudas de pimenteira-do-reino em substrato comercial fertilizado com adubo de liberação lenta. R Ceres. 59: 512-517.

Silva CF, Pereira MG, Miguel DL, Feitora JCF, Loss A, Menezes CEG \& Silva EMR (2012) Carbono orgânico total, biomassa microbiana e atividade enzimática do solo de áreas agrícolas, florestais e pastagem no médio 
Vale do Paraíba do Sul (RJ). R Bras Ci Solo. 36: 16801689.

Silva FC (2009) Manual de análises químicas de solos, plantas e fertilizantes. $2^{\mathrm{a}}$ ed. Brasília, Embrapa Informação Tecnológica. 627p.

Simas NK, Lima EC, Kuster RM, Lage CLS \& Oliveira Filho AM (2007) Potential use of Piper nigrum ethanol extract against pyrethroid-resistant Aedes aegypti larvae. R Soc Bras Med Trop. 40: 405-407.

Sundar-Raj CV \& Dhala S (1965) Effect on naturally occurring xanthines on bacteria. I. Antimicrobial action and potenting effect on antibiotic spectra. Appl Microbiol. 13: 432-436.

Thanuja TV, Hegde RV \& Sreenivasa MN (2002) Induction of rooting and root growth in black pepper cuttings (Piper nigrum L.) with the inoculation of arbuscular mycorrhizae. Scientia Horticulturae. 92: 339346.
Thomas RG \& Hay, MJM (2010) The role of nodal roots in prostate clonal herbs: 'phalanx' versus 'guerrilla'. Evol Ecol. 24: 1489-1504.

TV Gazeta. 2015. http://g1.globo.com/espiritosanto/agronegocios/noticia/2015/10/es-e-o-segundomaior-produtor-de-pimenta-do-reino-do-pais.html. Available at: Access: March 13th, 2014.

Wang X-L, Guo X-L, Hou X-G, Zhao W, Xu G-W \& Li Z-Q (2014) Effects of leaf zeatin and zeatin riboside induced by different clipping heights on the regrowth capacity of ryegrass. Ecol Res. 29: 167-180.

Zietemann C \& Roberto SR (2007) Efeito de diferentes substratos e épocas de coleta no enraizamento de estacas herbáceas de goiabeira, cvs. 'Paluma' e 'Século XXI'. R Bras Frutic. 29: 31-36. 